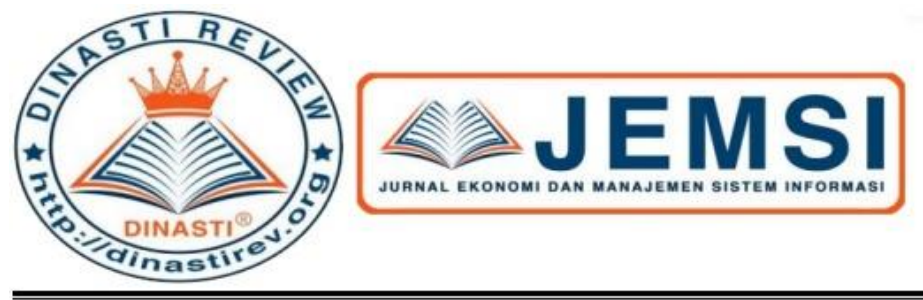

+62 878-9658-6407

087896586407 ()

https://dinastirev.org/JEMSI (-)

editor@dinastirev.org (G.

\title{
ANALISIS PENERAPAN ETIKA BISNIS PADA PT PLASTIK XYZ
}

\section{Nuur Apriliani Rahayu}

Magister Manajemen Program Studi Pascasarjana, Universitas Mercu Buana

ARTICLE INFORMATION $\quad$ Abstrak: Etika menjadi pembahasan yang penting

Received: 13 April 2020

Revised: 20 April 2020

Issued: 1 Mei 2020

dalam kegiatan bisnis saat ini, bahkan etika menjadi pusat sorotan bisnis. kontemporer. Etika bisnis ialah studi yang mempelajari moral yang baik dan tidak, yang berkonsentrasi pada standar moral sebagaimana

Corresponding author:

Nuur Apriliani Rahayu

E-mail: diterapkan dalam kebijakan, institusi, dan perilaku bisnis. PT. Plastik XYZ adalah perusahaan yang bergerak dibidang manufaktur yang menjalankan bisnisnya dibidang Recycling plastik. Tidak hanya Aprilapriliani17@gmail.com berorientasi pada keuntungan PT. Plastik XYZ juga melindungi hak konsumen, dimana visi perusahaan

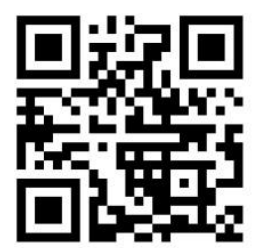

DOI:10.31933/JEMSI ialah dapat memberikan produk serta layanan yang terbaik sekaligus menjadi perusahaan yang dapat berkontribusi positif bagi lingkungan hidup. PT. Plastik XYZ juga menerapkan etika bisnis yang baik yaitu berkontribusi positif bagi lingkungan dan memberikan service terbaik kepada customer.

Kata Kunci: etika bisnis, recycling, customer.

\section{PENDAHULUAN}

Menurut Caza, Barker dan Camerin 2004 menjelaskan bahwa etika menjadi persoalan yang penting dalam aktifitas bisnis saat ini, bahkan etika menjadi pusat sorotan bisnis kontemporer. Etika bisnis ialah studi yang mempelajari moral yang baik dan tidak, yang berkonsentrasi pada standar moral yang diterapkan dalam kebijakan. (Velasques, 2005). (Ali, 2020) menerangkan bawah perlindungan konsumen adalah sekelompok undangundang dan organisasi yang dirancang untuk memastikan hak-hak konsumen serta perdagangan yang adil, persaingan dan informasi yang akurat di pasar. Undang-undang dirancang untuk mencegah bisnis yang terlibat dalam penipuan atau praktik-praktik tidak adil yang ditentukan dari mendapatkan keuntungan lebih dari pesaing.

Mereka juga dapat memberikan perlindungan tambahan bagi mereka yang paling rentan di masyarakat. Undang-undang perlindungan konsumen adalah bentuk peraturan pemerintah yang bertujuan untuk melindungi hak-hak konsumen. Contohnya, pemerintah mungkin mewajibkan perusahaan untuk mengungkapkan informasi terperinci tentang produk khususnya di area di mana keselamatan atau kesehatan masyarakat merupakan masalah, seperti makanan. Perlindungan konsumen berkaitan tentang gagasan hak konsumen, serta 
yang membantu konsumen membuat pilihan yang lebih baik di pasar dan mendapatkan bantuan terkait keluhan konsumen.

Kepentingan konsumen juga dapat dilindungi dengan mempromosikan persaingan di pasar yang secara langsung dan tidak langsung melayani konsumen, konsisten dengan efisiensi ekonomi, tetapi topik ini diperlakukan dalam hukum persaingan.

Perlindungan konsumen juga dapat ditegaskan melalui organisasi non-pemerintah dan individu sebagai aktivisme konsumen. (dalam Waples, Antes, Murphy, Connelly, \& Mumford, 2009). LeClair dan Ferrell mengemukakan, bahwa perkembangan zaman secara signifikan mempengaruhi perilaku etis serta kemajuan teknologi membuat perubahan yang serba cepat dan high impact terhadap keputusan yang menjadi bagian dari pekerjaan seharihari. (Waples, Antes, Murphy, Connelly, \& Mumford, 2009).

Hal ini memiliki makna yang penting untuk dibahas dikumudian hari dalam bidang pendidikan etika terhadap dunia pembelajaran dan semua pelaku professional dalam bisnis. Hal ini membuktikan bahwa etika bisnis merupakan hal penting agar siklus hidup suatu bisnis dapat bertahan lama, atau bahwa persyartan tumbuhnya sikap-sikap moral, khususnya sikap saling percaya, jujur, adil, dan tanggung jawab. Zaman yang berubah secara tidak langsung menuntut induvidu maupun perusahaanharus mengikuti zaman. Struktur nilai terhadap etika pun ikut mengalami perkembangan. Memang benar etika yang sudah ada tidak dapat menghilang seluruhnya, namun akan bermunculan etika atau aturan-aturan yang baru yang dianggap lebih cocok dengan masa yang saat ini.

PT Plastik XYZ merupakan perusahaan yang bergerak dalam bidang manufaktur di Jakarta. Selain itu, PT Plastik XYZ memberikan kualitas pelayanan dan kepuasan pelanggan dalam kinerjannya selama ini. PT Plastik XYZ berkomitmen mengutamakan keprofesionalan sebagai salah satu kunci utama dalam kelangsungan bisnisnya. Berdasarkan latar belakang yang sudah diuraikan, maka penelitian ini difokuskan kepada etika dalam berbisnis mana yang diterapkan pada PT Plastik XYZ. Sehingga penulis mengambil judul - Analisis Penerapan Etika Bisnis Pada PT Plastik XYZ. Maka perumusan masalah dan tujuan dari penelitian ini adalah menganalisis penerapan etika bisnis apa yang diterapkan di PT Plastik XYZ.

\section{KAJIAN PUSTAKA}

Kajian Pustaka dalam suatu pengaturan karya tulis ilmiah dapat diartikan sebagai penegasan terhadap keterbatasan karya ilmiah. Intisari dalam bagian ini dimuat secara lengkap di keyoword di bagian abstrak. Karena itu, persiapan karya tulis apa pun harus diwajibkan membuat studi literatur.

Agar tidak dianggap plagiarisme dari karya orang lain, penting bagi siapa pun untuk membuat tinjauan literatur dengan menulis ulang bahasa dan kata-kata yang diperoleh di bagian pencarian literatur. Sangat mudah untuk menggunakan kutipan langsung atau tidak langsung.

Etika dalam bahasa Yunani ialah ethos Keraf (1998) mengemukakan etika adalah adat istiadat atau kebiasaan yang akan membentuk aturan kuat di masyarakat, serta cara yang dilakukan mengikuti norma yang ada, dan norma tersebut membentuk sifat masyarakat dalam menghargai adat istiadat. Pengertian moral menurut Velasquez (2005) bahwa moral dapat mempengaruhi seseorang dalam memutuskan keputusan. Maka pengertian etika dan 
moralitas berbeda, etika ialah cabang filsafat yang menjelaskan tentang nilai dan norma moral yang menentukan perilaku manusia dalam hidupnya.

Terdapat banyak versi dari definisi etika bisnis dari berbagai pihak, dan berikut adalah beberapa definisi etika bisnis:

1) Menurut Laura Nash (1990), etika bisnis membahas mengenai bagaimana aturan sifat personal diterapkan dalam kegiatan dan visi perusahaan (dalam Sutrisna, 2010).

2) Etika bisnis adalah kata yang biasanya berhubungan dengan perilaku baik atau tidak baik yang dilakukan oleh manajer atau pemilik suatu organisasi (Griffin \& Ebert, 2007).

3) Menurut Velasques (2005), etika bisnis merupakan studi yang dikhususkan mengenai moral yang benar dan salah. Studi ini merfokus pada standar moral yang diterapkan dalam kebijakan, dan perilaku bisnis.

4) Irham Fahmi (2013) mengatakan bahwa, etika bisnis ialah aturan yang menegaskan suatu bisnis boleh bertindak dan tidak boleh bertindak, berdasarkan sumber tertulid maupun yang tidak tertulis. Jika suatu bisnis melanggar ketetapan tersebut maka akan mendapatkan sangsi secara langsung maupun tidak langsung.

Sutrisna (2010)menjelaskan, hal yang harus dikedepankan dalam bertindak ialah berdasrkan manfaat yang didapat. Sumber kesenangan diukur menurut intensitas dan lamanya perasaan tersebut. Perilaku dan perbuatan manusia dikatakan baik jika mendatangkan keuntungan dan kegunaan (Fahmi, 2013). Bertens (2013)menjelaskan, utilitarianisme ialah perbuatan yang dikatakan baik jika membawa manfaat, tapi manfaat yang dirasakan harus secara luas tidak hanya pada satu atau dua individu.

Teori ini berpendapat bahwa etika itu bersifat relatif (Fahmi, 2013). Menurut Faisal Badroen masalah lain yang timbul dalam praktiknya adalah self-centered (egois), sifat egois akan bertindak untuk diri individu, mengabaikan interaksi dengan pihak lain serta cepat mengambil keputusan tanpa memikir panjang, semua berfokus pada kriterianya sendiri (dalam Fahmi, 2013).

Keraf (1998) menjelaskan, prinsip-prinsip etika yang berlaku dalam bisnis adalah (dalam Sutrisna, 2010): otonomi, kejujuran, keadilan, saling menguntungkan, dan integritas moral.

Peranan etika dalam kegiatan bisnis antara lain, sebagai berikut:

1) Etika ialah aturan yang harus ada dalam kegiatan masyarakat serta perusahaan, yaitu tindakan yang baik dan tidak baik untuk dilakukan dalam bisnis diharapkan dapat menguntungkan banyak pihak yang terlibat (Satyanugraha, 2003).

2) Etika berperan sebagai penghubung pelaku bisnis. Untuk menjaga loyalitas konsumennya (Tjiptono, 2005).

3) Etika juga berperan sebagai syarat utama untuk konsistensi dan citra perusahaan dan loyalitas konsumen akan dapat membantu perusahaan agar tetap bisa bertahan (Tjiptono, 2005).

4) Untuk membangun kultur bisnis yang sehat, hal yang pertama dilakukan ialah menyusun norma perilaku sebelum aturan (hukum) perilaku dibuat dan laksanakan, 
atau aturan (norma) etika tersebut disahkan dalam bentuk aturan hukum (Arman, 2011).

5) Etika bisnis hanya bisa berperan dalam suatu komunitas yang baik (Arman, 2011). Perubahan yang cepat pada masa globalisasi ini, memiliki dampak yang berkaitan dengan sifat dalam berbisnis yang mengundang pro dan kontra dengan berbagai argumentasi. Dengan demikian, dapat diketahui bahwa manfaat etika bisnis menurut Sutrisna (2010) adalah sebagai berikut:

- Sebagai moralitas, etika bisnis mengarahkan tindakan manusia agar dapat mengatur kehidupan dan bisnis menjadi lebih baik.

- Dapat mengajak dan memberikan dampak positif untuk bersikap kritis serta rasional dalam mengambil dan dapat dipertanggung jawabkannya.

- Dapat membimbing masyarakat untuk menjadi masyarakat yang tertib, teratur, damai, dan sejahtera dengan mentaati aturan-aturan yang berlaku demi mencapai ketertiban dan kesejahteraan sosial.

- Sebagai ilmu pengetahuan, etika bisnis memberikan pemenuhan terhadap keingintahuan dan menuntut manusia untuk dapat berperilaku moral secara kritis dan rasional.

Sinour (2009) menjelaskan etika bisnis dapat memberikan keuntungan serta dapat membantu para pebisnis. Keuntungan yang dimaksud Sinour ialah sebagai berikut:

- Etika bisnis menyadarkan para pengusaha dimana dimensi etis yang ada melekat dalam perusahan yang dibangun.

- Etika bisnis memampukan para pengusaha untuk membuat moral dan ekonomi secara memadai.

- Etika bisnis memberi petunjuk bagi para pengusaha ketika akan menerapkan pertimbangan-pertimbangan dalam setiap kebijakan dan keputusan bisnis demi tercapainya tujuan yang ditargetkan.

Diperlukan pembanding antara etika bisnis dalam perusahan dengan hukum yang berlaku di Indonesia. Perbandingan tersebut dimaksudkan agar dapat membuktikan bahwa hukum yang berlaku di Indonesia telah memenuhi etika yang ada di masyarakat dan etika pada harfiahnya lebih tinggi dari pada hukum. Hal ini dibuktikan oleh Arman (2011) yang menjelaskan bahwa, hukum akan mengkodifikasi harapan dari etika dalam melaksanakan kegiatan bisnis. Walaupun disadari tidak semua harapan etika dapat dipenuhi oleh hukum. Norma etika memang bersifat dinamis, tetapi ketika etika dituangkan dalam ketentuan hukum sifat dinamisnya menjadi berkurang atau bahkan akan menjadi statis. Maka, hukum tentunya harus memperhatikan pula apabila adanya perubahan-perubahan.

Menurut Arman (2011) bahwa etika bisnis memiliki peranan yang lebih dibandingkan hukum, sebagai berikut:

Hukum sebagai salah satu sarana atau alat pengawasan (social control) yang paling efektif untuk mengendalikan praktek bisnis yang tidak sehat. Karena hukum menetapkan 
secara tegas apa yang seharusnya dilakukan serta yang tidak boleh dilakukan, serta bentuknya yang tertulis dapat memberi rasa aman bagi para pelaku bisnis, karena apabila terjadi pelanggaran sanksinya jelas.

$>$ Bisnis tidak bisa lepas dari faktor hukum, Bahkan pada taraf normatif, etika mendahului hukum. Adalah sebuah keharusan bisnis mematuhi hukum yang berlaku.

$>$ Etika bisnis mendasari terbentuknya hukum (substantif) bukan sebaliknya hukum yang membentuk etika bisnis. Etika sebagai bagian/cabang dari filafat (umum) yang mempelajari tentang tindakan manusia mengenai selayaknya bersikap dimasyarakat.

$>$ Filsafat hukum mempelajari tentang hakekat hukum, juga merupakan cabang filsafat (khusus). Keduanya (etika dan filsafat) yang pada dasarnya mengatur tinngkah laku manusia dalam bersosialisasi.

$>$ Etika berhubungan dengan apa yang seharusnya dilakukan dan tidak boleh dilakukan, sedangkan hukum cenderung ditafsirkan sebagai masalah legal atau ilegal.

$>$ Tidak semua etika diatur sepenuhnya oleh hukum, karena etika terus berkembang dalam kehidupan masyarakat yang mencerminkan pemikiran etis masyarakat dalam membangun etika bisnis, sedangkan hukum bersifat terbatas.

$>$ Namun demikian hukum harus dapat mengkodifikasikan harapan dari etika, meskipun disadari bahwa tidak semua harapan etika tersebut dapat dipenuhi seluruhnya oleh hukum.

(Tyas \& Ali 2016)Etika diterjemahkan sebagai acuan yang menyatakan apakah tindakan, aktivitas atau perilaku manusia bisa dianggap baik atau tidak. Sehingga etika bisnis mengacu dan akan berbicara mengenai masalah baik atau tidak baiknya suatu aktivitas bisnis. Mengacu kepada batasan etika dari berbagai pandangan ahli yang telah dikemukakan, maka peran etika bisnis adalah membahas dan memberikan jalan keluar dalam pemecahan masalah bisnis yang berlandaskan nilai-nilai moralitas dalam suatu kegiatan bisnis. Dasar yang diapakai dalam hal ini adalah prinsip, nilai serta norma-moral yang terwujud dalam sikap dan ucapan atau akhlak para pelaku bisnis dalam pelaksanaan usaha bisnisnya dengan menjunjung tinggi partisipan bisnisnya.

Penelitian yang dilakukan Mauro et al. (1999) tentang etika bisnis dan pengambilan keputusan perusahaan menggunakan definisi etika dan etika bisnis yang dikembangkan oleh Walton. Menurut Walton (1977 dalam Mauro, 1999):

Ethics. A critical analysis of human acts to determine their tightness or wrongness in terms of two major: truth and justice Business ethics. A range of criteria whereby human actions are judge to include such things as societal expectations: fair competition; the aesthetics or advertising and the used public relations; the meaning of social responsibilities; reconciling corporate behavior at home with behavior abroad; the extent of consumer sovereignty; the relevance of corporate size; the handling communications, and the like

Maksudnya, etika adalah analisa yang membahas sifat/tindakan manusia yang benar dan yang salah. Dalam kerangka terdapat 2 kriteria utama yang harus ada yaitu : kebenaran dan keadilan. Sedangkan etika bisnis merupakan beberapa kriteria yang dikumpulkan di mana tindakan manusia di nilai berdasarkan harapan masyarakat. Hasil penelitian Mouro (1999) 
menemukan bahwa "that personal and business ethics are not separate entities, that they coexist in the behavior of managers within the corporation, is supported in the current literature“.menjelaskan tentang etika personal dan etika bisnis ialah sebuah keutuhan yang tidak dapat dan keberadaannya saling melengkapi dalam mempengaruhi perilaku manajer. Banyak sumber-sumber terbaru yang mendukung perayataan dan hasil penelitian Mauro ini. Bagi mereka yang tidak mempunyai etika dalam berbisnis maka mereka yang hanya tergoda dengan keuntungan jangka pendek. Mereka yang menjadikan keuntungan sebagai tujuan utama yang dapat menyebabkan perusahaan akan mengambil keputusan yang tidak berlandaskan etika untuk mengejar keuntungannya. Dampaknya merekapun seringkali mengabaikan nilai-nilai etika bisnis. Bisnispun dijalankan secara tidak jujur, tidak adil, melanggar kewajaran, penuh mark-up.

\section{METODE PENELITIAN}

Dalam penelitian ini, peneliti menggunakan jenis penelitian kualitatif deskriptif. Penelitian kualitatif ialah penelitian yang bertujuan untuk memahami fenomena tentang apa yang dialami oleh subjek penelitian, secara holistik, dan dengan cara deskripsi dalam bentuk kata-kata dan bahasa, pada suatu konteks khusus yang alamiah dan dengan memanfaatkan berbagai metode alamiah (Moleong, 2013). Terdapat 11 karakteristik dalam penelitian kualitatif, salah satunya yaitu deskriptif.

Penelitian ini akan mendeskripsikan penerapan etika bisnis pada PT Plastik XYZ. Penerapan etika bisnis dideskripsikan meliputi penerapan etika bisnis yang mana yang diterapkan di PT Plastik XYZ. Subjek penelitian adalah sesuatu yang diteliti, baik itu orang, benda, ataupun lembaga/organisasi ataupun dokumen. Subjek penelitian pada dasarnya adalah yang akan dikenai kesimpulan hasil penelitian (Azwar, 2013).

Pada penelitian ini, peneliti melakukan penelitian pada PT Plastik XYZ di Jakarta. Perusahaan ini bergerak di bidang manufaktur. Objek penelitian adalah suatu atribut atau sifat atau nilai dari orang, objek kegiatan yang mempunyai variasi tertentu yang ditetapkan oleh peneliti untuk dipelajari dan kemudian ditarik kesimpulannya (Sugiyono, 2013).

Objek dalam penelitian ini adalah penerapan etika bisnis pada perusahan ekspedisi yakni, PT Plastik XYZ. Dimana penelitian penerapan etika bisnis mana yang diterapkan pada PT Plastik XYZ. Penelitian ini menggunakan jenis data kualitatif. Data kualitatif ialah data yang berbentuk kata-kata, bukan dalam bentuk angka (Sugiyono, 2013). Data kualitatif didapatkandari berbagai macam tmetode pengumpulan data seperti wawancara, analisia dokumen, dan observasi yang dituangkan dalam catatan lapangan (transkrip).

Sumber data yang digunakan oleh peneliti dalam penelitian ini ada dua macam, yaitu: sumber data primer pada penelitian ini diperoleh dari wawancara dan observasi yang dilakukan pada PT Plastik XYZ, dan sumber data sekunder dari penelitian ini bersumber dari dokumen-dokumen perusahaan seperti profil perusahaan, sejarah perusahaan, serta dokumendokumen lain yang terkait dengan penelitian.

Untuk memperoleh data-data yang diperlukan dalam penelitian ini, maka digunakan beberapa teknik yaitu: dengan teknik wawancara dan analisis dokumen. Tujuannya untuk menemukan permasalahan secara lebih terbuka, dimana pihak yang diwawancarai (interviewee) diminta pendapat dan ide-idenya tanpa terbatas hanya pada pertanyaan- 
pertannyaan yang diajukan oleh pewawancara (interviewer). Serta peneliti melakukan observasi. observasi yang digunakan dalam penelitian ini adalah jenis observasi tersamar.

Dalam observasi tersamar peneliti akan menyatakan terus terang kepada sumber data bahwa peneliti sedang melakukan penelitian. Jadi pihak yang diteliti mengetahui dari awal sampai akhir tentang aktivitas peneliti. Sehinga dalam observasi ini suatu saat peneliti juga tidak terus terang atau tersamar dalam hal observasi, hal ini untuk menghindari kalau suatu data yang dicari merupakan data yang masih dirahasiakan. Kemungkinan kalau dilakukan dengan terus terang maka peneliti tidak akan mendapatkan data yang valid.

Observasi ini dilakukan untuk melihat apakah penerapan nilai-nilai dalam perusahaan telah dilakukan sebagaimana mestinya atau tidak. Dalam penelitian ini teknik penentuan informan yang digunakan adalah dengan nonprobability sampling. Dengan menggunakan teknik purposive sampling penulis akan mengumpulkan sumber data dari informan di PT Plastik XYZ. Dalam menganalisa data yang ada penulis menstratifikasikan data, menjabarkan data sampai ke unit, melakukan sintesa, serta membuatnya kedalam pola, agarlebih mudah untuk memilih data yang penting dan difokuskan agar dapat memberikan kesimpulan yang dapat bermanfaat untuk orang lain. Menurut Sugiyono (2013), aktivitas dalam analisis data terbagi atas 3, yaitu: mereduksi data, penyajian data, dna kemudian melakukan penarikan kesimpulan/verifikasi. Dalam penelitian ini, peneliti menggunakan triangulasi untuk menguji keabsahan data yang digunakan. Peneliti memilih untuk menggunakan teknik triangulasi sumber. Dimana, triangulasi sumber merujuk pada upaya peneliti untuk mengakses sumbersumber yang lebih bervariasi guna memperoleh data berkenaan dengan persoalan yang sama (Pawito, 2007). Alasan penggunaan triangulasi sumber dikarenakan triangulasi sumber sesuai dengan kebutuhan dari penelitian yang ingin menguji kredibilitas data dengan cara mengecek data yang didapat, kemudian data tersebut dideskripsikan, dikategorisasikan dan dianalisis hingga tercipta suatu kesimpulan.

\section{HASIL DAN PEMBAHASAN}

Dari hasil wawancara, observasi dan analisis dokumen PT Plastik XYZ sebagai perusahaan publik, yang bergerak dalam bidang manufaktur, memiliki tanggung jawab yang besar kepada seluruh pemangku kepentingan. Sesuai dengan visi misi kami untuk erus meningkatkan kualitas produk dan pelayanan serta dapat berkontribusi dalam lingkungan hidup, kami terus melakukan penelaahan dan perbaikan atas pengelolaan Perusahaan yang saat ini diterapkan.

Sebagai perwujudan komitmen tersebut, jajaran direksi menetapkan etika bisisnya pada suatu pedoman etika yang diharapkan menjadi panduan bagi seluruh anggota organisasi PT Plastik XYZ, meliputi Komisaris, Direksi, dan segenap karyawan. Para pemimpin perusahaan mengharapkan komitmen dan tekad seluruh insan PT Plastik XYZ dari segenap jajaran untuk menerapkan Etika Bisnis PT Plastik XYZ.

\section{Etika Bisnis}

Etika Bisnis PT Plastik XYZ mengacu pada prinsip-prinsip utama tata kelola perusahaan yang baik berdasarkan visi dan misi perusahaan yaitu:

\section{Visi}


Menjadi perusahaan yang menjd teladan dalam menghasilkan produk dan layanan yang berkualias, serta memberikan kontribusi positif bagi lingkungan hidup dan memberikan kemajan kepada selurih pemegang kepentingan.

\section{Misi}

- Melakukan perbaikan secara terus menerus pada segala aspek agar selaku menjadi yang terdepan.

- Membangun jaringan pengumpul limbah plastik yang terluas di bidangnya.

- Membangun sumber daya manusia berkualias yang menopang kegiatan perusahaan dalam memberikan kontribusi positif bagi lingkungan hidup.

Etika Bisnis PT Plastik XYZ adalah sebagai berikut:

1) Standar Perilaku

Seluruh anggota organisasi PT Plastik XYZ menjalankan semua kegiatan dengan integritas, dan kejujuran

2) Kepatuhan terhadap Hukum dan Perundang-undangan

Seluruh anggota organisasi PT Plastik XYZ wajib mematuhi hukum dan peraturan perundang-undangan yang berlaku di Indonesia.

3) Komitmen terhadap Karyawan

PT Plastik XYZ menghargai keanekaragaman dan peran karyawan dalam mensukseskan kegiatan usaha, tidak membedakan suku dan ras dalam sebuah bidang atau dalam proses merekrut karyawan baru.

4) Integritas Bisnis

Seluruh anggota organisasi PT Plastik XYZ tidak menerima pemberian dalam bentuk apapun yang dapat mempengaruhi pengambilan keputusan.

5) Produk dan Layanan

PT Plastik XYZ selalu berkomitmen sesuai dengan misi perusahaan yang ingin memberikan layanan terbaik, maka PT. Plastik XYZ selalu mengedepankan pelayanan terbaik, menerima kembali produk retur, serta sealu membangun komunikasi yang baik kepada semua supplier.

6) Inovasi

PT Plastik XYZ menghargai hak atas kekayaan intelektual.

7) Komitmen terhadap Lingkungan

PT Plastik XYZ adalah perusahaan yang memiliki misi dapat berkontribusi positif bagi lingkungan hidup dimana diwujudkan produk kami lebih banyak menggunakan bahan recycling serta aktif dan bermitra dengan pihak lain terkait untuk pelestarian lingkungan hidup.

8) Kepatuhan terhadap Etika Bisnis PT Plastik XYZ

Direksi bertanggung jawab agar prinsip-prinsip Etika Bisnis PT Plastik XYZ dikomunikasikan, dipahami, dan diimplementasikan oleh semua anggota organisasi PT Plastik XYZ

9) Mekanisme Pelaporan Pelanggaran

PT Plastik XYZ membentuk Tim Tata Kelola untuk menindaklanjuti pelaporan pelanggaran maupun dugaan pelanggaran Etika Bisnis. Tim Tata Kelola diketuai oleh Direktur Independen dengan didukung oleh fungsi Audit Internal (Internal Audit), 
Hukum (Legal), Sumber Daya Manusia (Human Resource), Kualitas Sistem atau (Quality Manajemen System) ataupun pihak ketiga lainnya yang ditunjuk. Tim Tata Kelola mendokumentasikan seluruh pelaporan yang diterima berikut tindak lanjutnya sebagai Pembelajaran bagi organisasi untuk memperbaiki proses bisnis dan memperkuat pengendalian internal. Tim Tata Kelola secara berkala menyampaikan laporan kepada Dewan Komisaris.

\section{0) Pengertian Umum Etika:}

Standar perilaku dalam suatu komunitas, yang menyatakan perbuatan mana yang baik, yang selayaknya dilakukan dan perbuatan mana yang buruk yang selayaknya dihindari sesuai dengan norma-norma yang berlaku.

11) Mekanisme Pelaporan Pelanggaran Ruang Lingkup Pelaksanaan Penerapan mekanisme pelaporan pelanggaran berlaku untuk Dewan Komisaris, Komite-komite di bawah Dewan Komisaris, Direksi, dan seluruh karyawan PT Plastik XYZ dalam menerapkan dan menjunjung tinggi pedoman etika dan nilai-nilai tata kelola dalam aktivitas pekerjaan sehari-hari.

\section{Manfaat Mekanisme Pelaporan Pelanggaran}

Berikut adalah manfaat yang diharapkan dari penerapan Mekanisme Pelaporan Pelanggaran:

a) Timbulnya keengganan untuk melakukan pelanggaran dan meningkatkan kesadaran untuk melaporkan permasalahan sesuai mekanisme yang berlaku.

b) Terdapat mitigasi sebelum kemungkinan masalah yang ada terjadi pada perusahaan.

c) Tersedianya kesempatan untuk menangani permasalahan secara internal tuntk meminimalasir berita yang keluar perusahaan.

d) Minimalisasi biaya dalam mekanisme pelaporan dan penanganan permasalahan.

e) Peningkatan citra dan reputasi Perusahaan di mata pemangku kepentingan, dan masyarakat umum.

f) Memberikan masukan terkait peningkatan kualitas sistem manajemen

g) Menciptakan iklim profesionalisme yang lebih kondusif dalam bekerja.

\section{Ketentuan Umum Penanganan Pelaporan Pelanggaran}

\section{A. Ruang Lingkup Permasalahan}

Lingkup pelaporan pelanggaran yang akan ditindaklanjuti adalah permasalahan terkait prinsip-prinsip tata kelola perusahaan yang baik, nilai-nilai etika, serta peraturan perundangundangan yang dapat merugikan Perusahaan, antara lain meliputi permasalahan sebagai berikut, serta bukan merupakan keluhan pribadi atas kebijakan Perusahaan tertentu.

a) Permasalahan terkait peraturan dan perundang-undangan yang berlaku.

b) Permasalahan terkait Etika Bisnis PT Plastik XYZ, termasuk penyalah gunaan jabatan untuk kepentingan pribadi, pemerasan, tindakan kecurangan, benturan kepentingan, gratifikasi dan lain-lain.

c) Penyimpangan dari Peraturan Perusahaan yang berlaku termasuk kebijakan dan prosedur operasional.

d) Permasalahan terkait prinsip akuntansi yang berlaku umum. 
e) Tindakan yang membahayakan keselamatan kerja.

\section{B. Kebijakan Umum Perusahaan untuk Menerima dan Menyelesaikan Pelaporan Pelanggaran}

a) Perusahaan menerima pelaporan pelanggaran dari pihak yang berasal dari kalangan internal Perusahaan dengan identitas yang jelas. Pemberi informasi wajib mencantumkan identitas (nama, jabatan, perusahaan) dan kartu karyawan serta data pendukung yang berkaitan dengan permasalahan yang dilaporkan.

b) Pelaporan pelanggaran harus disertai data pendukung, bukti, informasi atau indikasi yang jelas untuk menindaklanjuti permasalahan.

c) Perusahaan wajib menindaklanjuti penanganan terhadap laporan pelanggaran sesuai dengan alur yang ada dan peraturan perundang-undangan yang berlaku.

d) Pelaporan pelanggaran agar mencantumkan jenis permasalahan, pihak yang terlibat, lokasi

kejadian, waktu, bukti pendukung dan hal-hal lain yang dianggap relevan.

e) Perusahaan berkomitmen menjamin kerahasiaan identitas pemberi informasi dan menyampaikan informasi tindak lanjut secara rahasia kepada pemberi informasi.

f) Perusahaan berkomitmen melindung pemberi informasi dari tindakan balasan, antara lain dalam bentuk tekanan seperti pemecatan, penurunan jabatan, penundaan kenaikan jabatan secara tidak adil, serta memberikan bantuan perlindungan terhadap gugatan hukum dan tindakan fisik.

\section{Perubahan atas Kebijakan Pelaporan Pelanggaran}

Kebijakan pelaporan pelanggaran dapat mengalami penyesuaian dari waktu ke waktu sejalan dengan perkembangan Perusahaan, praktik tata kelola, dan hal -hal lainnya. Setiap perubahan akan dilaksanakan setelah memperoleh persetujuan Dewan Komisaris..

\section{Ketentuan Umum Penanganan Pergantian Produk Return Sebagai Hak Konsumen}

Lingkup pelaporan penanganan terkait produk return akan ditindaklanjuti adalah permasalahan terkait kualitas produk dimana perusahaan akan memberikan pelayanan dan produk terbaik kepada setiap supplier, dimana pihak konsumen berhak mendapatkan haknya yaitu mendapatkan produk yang berkualitas. Pihak perusahaan akan memberikan timbal balik lebih jika produk yang di return terkait dengan permasalahan kualitas sebagai bentuk tanggung jawab perusahaan dalam memenuhi kepuasan konsumen.

\section{Etika Bisnis Perusahaan Dengan Pemangku Kepentingan}

\section{Distributor}

1. Sebagai perusahaan yang menerapkan etika bisnis PT Plastik XYZ tidak akan memberikan informasi terkait semua distributor yang melakukan kerja sama dengan PT. Plastik XYZ.

2. PT. Plastik XYZ tidak akan menjalin kerjasama jika dalam area pemasaran jika pada regional tersebut sudah terdapat distributor yang lebih dulu melakukan kerja sama agar tidak terjadi persaingan antar distributor.

3. PT. Plastik XYZ menerima return barang terkait kualitas maupun dikarenakan kesalahan pihak ke3 sebagai tanda PT. Plastik XYZ selalu mementingkan kepuasan konsumen. 


\section{KESIMPULAN DAN SARAN}

\section{Kesimpulan}

Setelah peneliti mengamati dan menganalisis adalah konsep etika bisnis apa yang diterapkan di PT Plastik XYZ, maka dapat disimpulkan bahwa penerapan etika bisnis di PT Plastik XYZ baik dalam menerapkan etika bisnis.

\section{Saran}

Berdasarkan hasil penelitian dan analisa, peneliti ingin memberikan saran yang sekiranya dapat bermanfaat bagi PT Plastik XYZ untuk memajukan perusahaan, yaitu perlu dilakukan update sesuai perkembangan jaman terkait etika bisnis di bidang manufaktur plastik.

\section{DAFTAR RUJUKAN}

Ali Hapzi, 2020. Modul BE \& GG, Univeristas Mercu Buana

Amran, S (2011). Etika dan hukum bisnis. Retrieved March 02, 2020, from

http://digemesta.com/indo/ei=kIrFU5 IPNWRuASr9oL4Bw\&usg=AFQjCNEhFwiPu

GovTSciOeLaOCRGccwssQ\&bvm=bv.70810081,d.c2E/etika-dan-hukum-dalam-

bisnis.pdf

Azwar, S (2013). Metode penelitian. Yogyakarta: Pustaka Pelajar.

Bertens, K. (2013). Pengantar etika bisnis. Yogyakarta: Kanisius.

Bungin, B. (2009). Penelitian kualitatif. Jakarta: Kencana.

Caza, A., Barker, B. A., \& Cameron, K. S. (2004). Ethics and ethos: The buffering

and amplifying effects of ethical behavior and virtuousness. Journal of Business Ethics, 52 (2), 169-178. Retrieved February 3 2020, from http://search.proquest.com/docview/198094244?accountid=45762

Cornwell, B. (2005). A cross-cultural study of the role of religion in consumers' ethical positions. Journal: International Marketing Review - INT MARK REV, vol. 22, no. 5. Retrieved February 3, 2020, from http://academic.research.microsoft.com/Publication/37817220/a-cross-culturalstudy-of-the-roleof-religion-in-consumers-ethical-positions

Dinas Tenaga Kerja dan Transmigrasi Kabupaten Temanggung Jawa Tengah (2009). Pengesahan Pembentukan Panitia Pembina Keselamatan dan Kesehatan Kerja (P2K3). Retrieved March 14, 2020, from http://dinnakertrans.temanggungkab.go.id/detail layanan. php?bdid=2\&biid=10

Fahmi, I. (2013). Definisi etika bisnis. Etika bisnis: teori kasus, dan solusi. Bandung: Alfabeta.

Griffin, R.W., \& Elbert, R.J. (2007). Business edisi 8. Jakarta: Erlangga.

Huntsman, J.M. (2005). Winner never cheat: even in difficult times, new and expanded edition.Philadelphia: The Wharton School and Pearson Education.

Indounas, K. (2008). The relationship between pricing and ethics in two industrial service industries. The Journal of Business \& Industrial Marketing, 23(3), 161-169. Retrieved March 14, 2020, from doi:http://dx.doi.org/10.1108/08858620810858427 
Keraf, A.S. (1998). Etika bisnis: tuntutan dan relevansinya. Yogyakarta: Kanisius.

Lennick, D., \& Keil, F. (2005). Moral intelligence: enhanching business performance and leadership success. Philadelphia: The Wharton School and Pearson Education.

Michaelson, C. Moral. (2008). Luck and Business Ethics. Journal of Business Ethics, 773787. Retrieved March 3, 2020, from http://search.proquest.com/docview/198039827/fulltextPDF/14121BCFCD84E8D5 E4D/1?accountid=45762

Moleong, L.J. (2013). Metode penelitian kualitatif, edisi revisi. Bandung: PT Remaja Rosdakarya.

Pawito. (2007). Penelitian komunikasi kualitatif. Yogyakarta: PT LKiS Pelangi Aksara.

Piercy, N. F., \& Lane, N. (2007). Ethical and moral dilemmas associated with strategic relationships between business-to-business buyers and sellers. Journal of Business Ethics, 72(1), 87-102. Retrieved March 14, 2020, from doi:http://dx.doi.org/10.1007/s10551-006-9158-6

Rudito, Bambang, dan Melia Famiola. 2007, Etika Bisnis dan Tanggung Jawab Sosial Perusahaan di Indonesia. Bandung : Rekayasa Sains

Satyanugraha, H. (2003). Etika bisnis: tuntutan \& relevansinya. Jakarta: Kanisius.

Sinour, Y.L. (2009). Etika bisnis. Jakarta: Yayasan Pustaka Obor Indonesia.

Story, J., \& Hess, J. (2010). Ethical brand management: Customer relationships and ethical duties. The Journal of Product and Brand Management, 19(4), 240-249. Retrieve March 14, 2020, from doi:http://dx.doi.org/10.1108/10610421011059568

Sugiyono. (2010). Metode penelitian bisnis: pendekatan kuantitatif, kualitatif, dan R \& D. Bandung : Alfabeta.

Sugiyono. (2013). Memahami penelitian kualitatif. Bandung: Alfabeta.

Sugiyono. (2013). Metode penelitian kuantitatif dan kualitatif dan R \& D. Bandung: Alfabeta.

Sutrisna, D. (2010). Etika bisnis: konsep dasar implementasi dan kasus. Bali: Udayana University Press.

Svensson, G., \& Wood, G. (2011). A conceptual framework of corporate and business ethics across organizations. The Learning Organization, 18(1), 21-35. Retrieved March 16, 2020, from doi:http://dx.doi.org/10.1108/09696471111095975

Tjiptono, F. (2005). Pemasaran Jasa. Malang: Bayumedia Publising.

Tyas, N. S., \& Ali, H. (2016). ANALISIS PENERAPAN ETIKA BISNIS PADA PT

PERUSAHAAN FARMASI PT X. 2-13.

Velasquez, M.G (2005). Etika bisnis, konsep dan kasus edisi 5. Yogyakarta: Penerbit Andi.

Waples, E.P., Antes, A.L., Murphy, S.T., Connelly, S., \& Mumford, M.D. (2009). A metaanalyticinvestigation of business ethics instruction. Journal of Business Ethics, 87(1), 133-151. Retrieved March 19, 2014, from doi:http://dx.doi.org/10.1007/s10551-008-9875-0

Widianto, E. (2020, March 27). Aburizal Bakrie berkukuh Lapindo tidak bersalah. Tempo News. Retrieved March 23, 2020, from http://www.tempo.co/read/news/2014/03/27/063565959/AburizalBakrie-

Berkukuh-Lapindo-Tid k-Bersalah

Workplace Safety and Health. National Institute of Occupational Safety an Health. (n.d.). Retrieved March 20, 2020, from http://www.cdc.gov/niosh/topics/healthcare/ 